\title{
ACADEMIC TRAINING IN SPANISH UNIVERSITIES FOR THE DIDACTIC USE OF CINEMA IN PRE-SCHOOL AND PRIMARY EDUCATION
}

\author{
Alejandro Lorenzo-Lledó (iD), Asunción Lledó $(\mathbb{D}$, Gonzalo Lorenzo $(\mathbb{D}$, Elena Pérez-Vázquez (D) \\ University of Alicante (Spain) \\ alejandro.lorenzo@ua.es, asuncion.lledo@ua.es,glledo@ua.es, elena.pv@ua.es
}

Received November 2020

Accepted December 2020

\section{Abstract}

One of the characteristic features of current society is the relevance of technology and audiovisual media. This fact has generated demands in the educational field to adapt objectives and methodologies to non-textual languages. Among the predominant audiovisual media is the cinema, which has many potentialities as a didactic resource. Therefore, the aim of this study was to find out the training that students of the Teacher's Degree in Spanish universities receive for the didactic use of cinema through a nationwide research with survey design in which 4659 students, belonging to all the Autonomous Communities and 58 universities, participated. The questionnaire called Perceptions about the potentialities of cinema as a didactic resource in pre-school and primary classrooms (PECID) was designed ad hoc. This questionnaire, which consists of 45 items, has a section that deals with the training received for the educational use of cinema. The Spanish universities offering the Teacher Degree were identified and contacted for the dissemination of the questionnaire. The results obtained showed that $88.4 \%$ had not received training. Furthermore, 250 subjects were identified in which film content is taught, mostly in the second and third year and in the area of Didactics and School Organization. It was also found that the most frequent activities carried out are the viewing of films with individual answers to questions and the film forum. This pioneering study in Spain aims to provide information as a basis for further academic training in cinema as a resource of high educational value.

Keywords - Cinema, Audiovisual media, Didactic resource, Academic training, Teacher's degree, University education.

\section{To cite this article:}

Lorenzo-Lledó, A., Lledó, A., Lorenzo, G., \& Pérez-Vázquez. E. (2021). Academic training in Spanish universities for the didactic use of cinema in pre-school and primary education. Journal of Technology and Science Education, 11(1), 210-226. https://doi.org/10.3926/jotse.1162

\section{Introduction}

The university, as an institution of university education, must aspire to excellence, be in touch with society and drive change and innovation. In this sense, it must base its identity on training reflective people, since, as Freire (1975: page 18) indicated "education does not change the world, it changes the people who are going to change the world". De la Herrán and Álvarez (2010) add that the university must first lead and then cooperate in the work of intellectual enquiry, generating self-criticism and deep reflection. All of this must necessarily be in line with the response to new social demands. 
The change of paradigm in university education has been driven by competence-based learning, which aims to meet the requirements of current society, offering, as indicated by Arráez Jensen and Pascual (2013), a global education in which university students can interrelate the knowledge they acquire with their future entry into the labour market. In this context, university teaching staff must take on new methodological challenges in order to satisfy an education not only as a sum of professional skills, but also as an integral training of people. Likewise, it should be borne in mind that a higher education of excellence is linked to a university accessible to all, which must guarantee the presence, participation and academic achievements of all students in equal opportunities (Lorenzo-Lledó, Lorenzo, Lledó \& Pérez-Vázquez, 2020).

In addition to the new educational demands that have emerged, the irruption of technologies and audiovisual media in the design of new training frameworks. In this sense, from the almost exclusive predominance of one type of code and literacy, such as reading and writing, there has been a gradual move towards other forms of representation and expression, in line with today's society in which, as Cabero and Córdoba (2009) note, there is a galaxy of technologies and a great diversity of languages and symbolic systems that generate the need to master different types of code. Among the existing audiovisual resources, there is the cinema, which, as Amar (2009) emphasises, is a synthesis of all the arts, and which, due to its pedagogical value, treasures numerous educational possibilities (Ambròs \& Breu, 2011).

In accordance with the normative framework of the area in which this paper is developed, that is to say, initial teacher training in Spain, Order ECI/3854/2007, of 27 December and Order ECI/3857/2007, of 27 December, were enacted to regulate the verification of official university degrees that qualify for the exercise of the profession of Pre-school and Primary Education Teacher. The former establishes a series of competencies that teachers in pre-school education must have within a globalized educational model, in which cinema can be integrated, and specifically prescribes "mastering the use of different techniques of expression", such as filmmaking and "knowing the educational implications of information and communication technologies", even if only television is expressly mentioned. On the other hand, for the Primary Education Teacher, it is established to know how to "promote democratic education for active citizenship", which is in line with one of the objectives of including cinema in the classroom in its critical dimension. In addition, it is established to "know and apply in the classrooms the information and communication technologies", expressly mentioning to know how to "selectively discern the audiovisual information that contributes to learning, civic training and cultural richness".

For its part, the Spanish educational laws related to the professional field of the Teacher's Degree, as is the case of the Organic Law 8/2013 for the Improvement of Educational Quality (2013), which repeals part of the previous Organic Law 2/2006 on Education (2006), establishes as objectives "to use different artistic representations and expressions and to begin to build visual and audiovisual proposals" or to promote "the knowledge of different artistic languages". Furthermore, the studies by Ramírez, Renés and García-Ruiz, (2014), Ramírez, Renés and Aguaded, (2016), Ramírez, Renés and González, (2018), and Lara, Ruiz and Tarín (2019) have analysed the presence of the media and cinema in the Spanish curricular frameworks of the compulsory education stages. The last three authors have found that cinema is present in the regional curricula of Pre-school and Primary Education, although in an unequal way. In this sense, in Primary Education, the cinema as a resource of educational support is included in all the communities, but only in the Community of Madrid and in Andalusia is it also present at the same time as a critical analysis of the audiovisual, as a form of own production of films and as a form of art.

Based on the above, it is worth asking how the Spanish university is meeting these training requirements in the training of future teachers. Some research has analysed the curricula of some universities and how they are tackling the development of digital competence (Gewerc \& Montero, 2015; Ortega, 2015; Cabero, 2017; Muñoz \& Cubo, 2019; Fuentes, López \& Pozo, 2019) and the media competence (López \& Aguaded, 2015; Gozálvez, Masanet, Hernando \& Bernal-Bravo, 2019), but not the teaching competence to apply cinema in education, nor from a national scope, identifying a relevant research gap. Therefore, the general objective of this study is to know the training received by students of the Teacher Degree in Spanish universities for the educational use of cinema. The following specific objectives are based on this general objective: 
1. To analyse whether students in the Teacher's Degree are receiving training in the educational use of film, considering the national scope, the Autonomous Community, the type of Teacher's Degree and the ownership of the university.

2. To identify the subjects where specific content is taught for the educational use of film, based on the university, the Autonomous Community, the ownership of the university, the type of Teacher's Degree and its characterization in the curriculum.

3. To know the activities that the teachers of the Teacher's Degree conduct using film as a teaching resource and the frequency of application.

4. To detect whether students in the Teacher's Degree consider necessary further specific training to use film as a teaching resource in the classroom.

\section{Method}

The research conducted is descriptive and survey-based. The survey design is widely used in the education field, especially when large samples are to be collected from various strata or territories. In this sense, Arnau (1996) indicates that survey designs are aimed at obtaining quantitative information about the characteristics of a given population, making it possible to describe them.

\subsection{Participants}

In the case of a national study, the participating sample was 4659 students from all the Autonomous Communities and 58 universities, 39 public and 19 privates, following a quota sampling (Bisquerra, 2014). Of the mentioned sample, $15.5 \%(\mathrm{n}=720)$ of the participants were men and $84.5 \%(\mathrm{n}=3939)$ women and had an average age of 22.3 years $(\mathrm{SD}=3.9)$. On the other hand, $51.0 \%(\mathrm{n}=2378)$ were from the Primary School Teacher's Degree and 49.0\% $(\mathrm{n}=2281)$ were from the Pre-school Teacher's Degree. Furthermore, $89.8 \%(n=4183)$ of the participants were from public universities and 10.2\% ( $n=476)$ from private universities. If we look at the territorial distribution, below, in figure 1, we present the frequencies and percentages of the participating students according to the Autonomous Community.

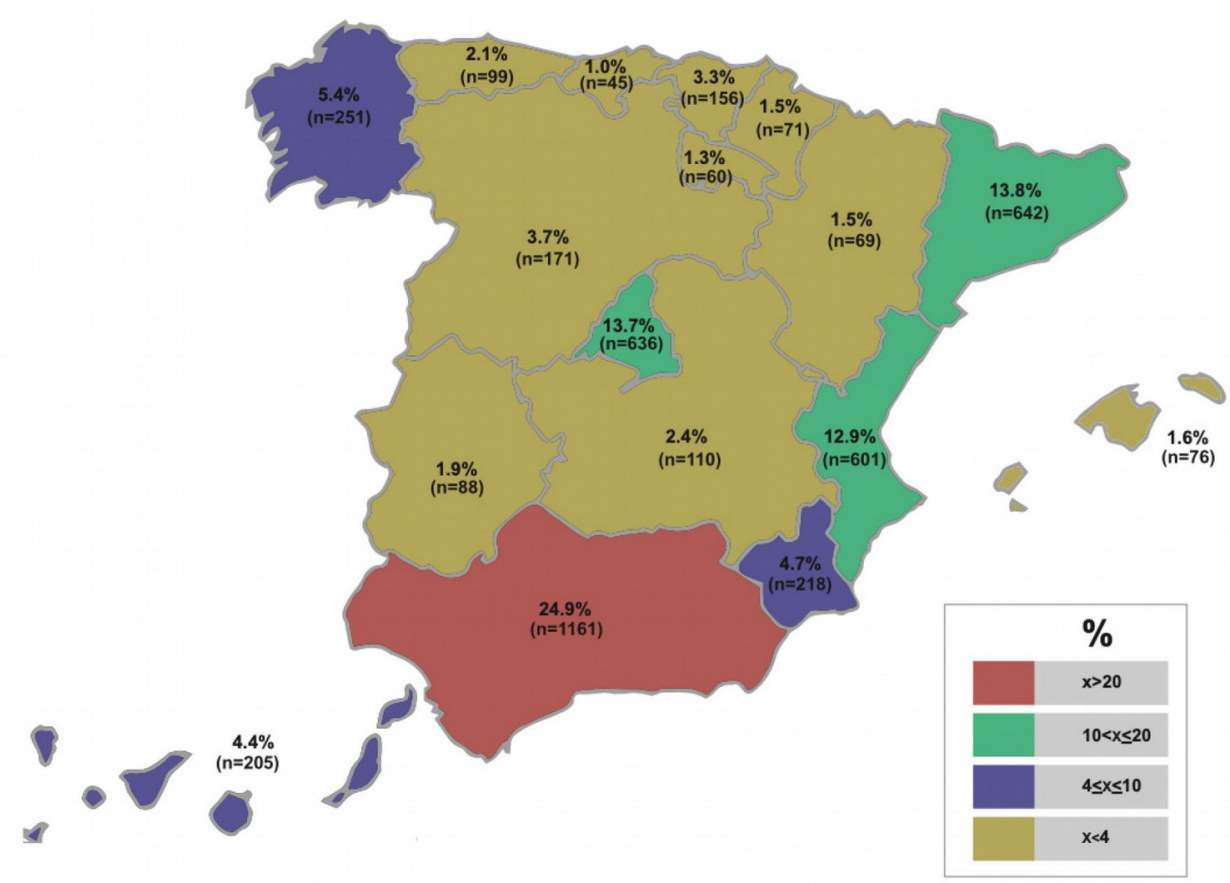

Figure 1. Percentages and frequencies of the sample according to the Autonomous Community

(Lorenzo-Lledó, 2020) 
As far as the universities are concerned, table 1 shows the participating students according to the university they belong to.

\begin{tabular}{|c|c|c|}
\hline University & f & $\%$ \\
\hline University of A Coruña & 119 & 2.6 \\
\hline University of Alcalá & 166 & 3.6 \\
\hline Alfonso X El Sabio University & 3 & 0.1 \\
\hline University of Alicante & 196 & 4.2 \\
\hline University of Almería & 23 & 0.5 \\
\hline Nebrija University & 19 & 0.4 \\
\hline Autonomous University of Barcelona & 73 & 1.6 \\
\hline Autonomous University of Madrid & 154 & 3.3 \\
\hline University of Barcelona & 64 & 1.4 \\
\hline University of Burgos & 24 & 0.5 \\
\hline University of Cádiz & 155 & 3.3 \\
\hline Camilo José Cela University & 24 & 0.5 \\
\hline University of Cantabria & 41 & 0.9 \\
\hline CEU Cardenal Herrera University & 35 & 0.8 \\
\hline University of Castilla-La Mancha & 110 & 2.4 \\
\hline Catholic University San Antonio & 33 & 0.7 \\
\hline Catholic University Santa Teresa de Jesús de Ávila & 2 & 0.0 \\
\hline Valencia Catholic University San Vicente Mártir & 9 & 0.2 \\
\hline Complutense University of Madrid & 45 & 1.0 \\
\hline University of Córdoba & 224 & 4.8 \\
\hline University of Deusto & 13 & 0.3 \\
\hline European University of the Atlantic & 4 & 0.1 \\
\hline University of Extremadura & 88 & 1.9 \\
\hline Francisco de Vitoria University & 13 & 0.3 \\
\hline University of Girona & 158 & 3.4 \\
\hline University of Granada & 116 & 2.5 \\
\hline University of Huelva & 101 & 2.2 \\
\hline University of the Islas Baleares & 76 & 1.6 \\
\hline International University of Cataluña & 8 & 0.2 \\
\hline Jaume I University & 223 & 4.8 \\
\hline University of Jaén & 25 & 0.5 \\
\hline University of La Laguna & 88 & 1.9 \\
\hline University of La Rioja & 60 & 1.3 \\
\hline University of Las Palmas de Gran Canaria & 117 & 2.5 \\
\hline University of León & 27 & 0.6 \\
\hline University of Lleida & 111 & 2.4 \\
\hline Loyola University Andalucía & 30 & 0.6 \\
\hline Mondragón University & 70 & 1.5 \\
\hline University of Murcia & 185 & 4.0 \\
\hline University of Málaga & 186 & 4.0 \\
\hline University of Navarra & 23 & 0.5 \\
\hline University of Oviedo & 99 & 2.1 \\
\hline University of País Vasco & 73 & 1.6 \\
\hline Comillas Pontifical University & 32 & 0.7 \\
\hline Pontifical University of Salamanca & 33 & 0.7 \\
\hline
\end{tabular}




\begin{tabular}{|l|r|r|}
\hline \multicolumn{1}{|c|}{ University } & f & \multicolumn{1}{c|}{$\%$} \\
\hline Public University of Navarra & 48 & 1.0 \\
\hline Ramon Llull University & 96 & 2.1 \\
\hline Rey Juan Carlos University & 180 & 3.9 \\
\hline Rovira i Virgili University & 118 & 2.5 \\
\hline University of Salamanca & 54 & 1.2 \\
\hline San Jorge University & 15 & 0.3 \\
\hline University of Santiago de Compostela & 35 & 0.8 \\
\hline University of Sevilla & 301 & 6.5 \\
\hline University of Valladolid & 31 & 0.7 \\
\hline University of Valencia & 138 & 3.0 \\
\hline University of Vic & 14 & 0.3 \\
\hline University of Vigo & 97 & 2.1 \\
\hline University of Zaragoza & 54 & 1.2 \\
\hline Total & 4659 & 100.0 \\
\hline
\end{tabular}

Table 1. Sample participants according to university (Lorenzo-Lledó, 2020)

The total sample is representative of the analysed population with a sampling error of $1.4 \%$ and a confidence level of $95.5 \%$.

\subsection{Instrument}

The questionnaire Perceptions about the potentialities of cinema as a didactic resource in pre-school and primary classrooms (PECID) was used for data collection. It was designed ad hoc for the research and consists of 45 items, distributed in two parts. In this sense, the third section of the first part of the questionnaire, with 11 items, focuses on the training received for the use of cinema as a didactic resource (Lorenzo-Lledó, 2020). The results presented are those relating to the items on whether training has been received in the Teacher Degree, in which subject or subjects, how many hours of training and the frequency with which teachers have participated in activities in which cinema is the teaching resource. In addition, an item is included that focuses on the students' perception of the need to receive specific training to use film as a teaching resource in the classroom. These items were subjected to expert judgement, applying the Content Validity Coefficient (Hernández-Nieto, 2002). Thus, values higher than 0.80 were obtained, reflecting good content validity.

\subsection{Procedure}

In the first phase of the study, we proceeded to identify the Spanish universities, both public and private, in the different Autonomous Communities that offered the Teacher's Degree. In the second phase, teachers were contacted by email, informing them of the objectives of the research and requesting their collaboration in disseminating the questionnaire to their students. Finally, in the third phase, data collection was carried out. The students filled in the questionnaire during the academic year 2018/2019 through the Google Forms tool, informing themselves beforehand that it was a totally anonymous and voluntary activity.

\subsection{Data Analysis}

Once the data collection procedure had been planned and implemented, the data were analysed using version 21 of the SPSS statistical package for social sciences. Depending on the research design chosen, the descriptive statistics were analysed using frequencies, percentages and mean.

\section{Results}

The results of the study are presented below, grouped according to the quantified variables. 


\subsection{Training Received for the Didactic Use of Cinema}

In relation to the results obtained on the existence of specific training in the Teacher's Degree for the use of cinema as a teaching resource, a very high percentage of students of the Teacher's Degree in Spanish universities $(88.4 \% ; \mathrm{n}=4117)$ have not received specific training to use cinema in the classroom, stating only $11.6 \%(\mathrm{n}=542)$ that they did receive training. To analyse the training received according to the Autonomous Community, Table 2 is presented.

From the results obtained, it can be seen that in the different Autonomous Communities there is a predominance of students who have not received training, with the exception of Cantabria, where 55.6\% claim to have received specific training for the didactic use of cinema. However, it should be pointed out that there is no Autonomous Community where no training is provided to its students. In addition to Cantabria, communities such as Asturias, La Rioja and Navarre have a notable percentage of trained students, $33.3 \%, 31.7 \%$ and $23.9 \%$ respectively. With a percentage of students with training of less than $20.0 \%$, mention should be made of Murcia (18.3\%), Aragon (14.5\%) and Andalusia (15.0\%). The Communities with the lowest percentage of trained students are Catalonia and the Basque Country, with $4.8 \%$ and $3.8 \%$.

Regarding the percentage of students who have received training according to the type of Teacher Degree, the percentages are very similar, with no more than $85.0 \%$ of the participating students having received training in the two degrees. Nevertheless, the percentage of pupils in the Primary Education Degree who have received training is slightly higher, $13.9 \%(n=35)$ compared to $9.3 \%(n=19)$ of pupils in the Pre-school Education Degree.

\begin{tabular}{|c|c|c|c|c|c|c|c|c|c|}
\hline \multicolumn{10}{|c|}{ Training in the didactic use of cinema } \\
\hline \multirow[b]{2}{*}{$\begin{array}{l}\text { Autonomous } \\
\text { community }\end{array}$} & \multicolumn{3}{|c|}{ Yes } & \multicolumn{3}{|c|}{ No } & \multicolumn{3}{|c|}{ Total } \\
\hline & f & $\begin{array}{c}\% \\
\mathrm{AACC}\end{array}$ & $\begin{array}{c}\% \\
\text { Spain }\end{array}$ & f & $\begin{array}{c}\% \\
\mathrm{AACC}\end{array}$ & $\begin{array}{c}\% \\
\text { Spain }\end{array}$ & f & $\begin{array}{c}\% \\
\mathrm{AACC}\end{array}$ & $\begin{array}{c}\% \\
\text { Spain }\end{array}$ \\
\hline Andalusia & 174 & 15.0 & 3.7 & 987 & 85.0 & 21.2 & 1161 & 100.0 & 24.9 \\
\hline Aragon & 10 & 14.5 & 0.2 & 59 & 85.5 & 1.3 & 69 & 100.0 & 1.5 \\
\hline Asturias & 33 & 33.3 & 0.7 & 66 & 66.7 & 1.3 & 99 & 100.0 & 2.1 \\
\hline Balearic Islands & 5 & 6.6 & 0.1 & 71 & 93.4 & 1.5 & 76 & 100.0 & 1.6 \\
\hline Canary Islans & 17 & 8.3 & 0.4 & 188 & 91.7 & 4.0 & 205 & 100.0 & 4.4 \\
\hline Cantabria & 25 & 55.6 & 0.5 & 20 & 44.4 & 0.4 & 45 & 100.0 & 1.0 \\
\hline Castilla - La Mancha & 7 & 6.4 & 0.2 & 103 & 93.6 & 2.2 & 110 & 100.0 & 2.4 \\
\hline Castile and Leon & 13 & 7.6 & 0.3 & 158 & 92.4 & 3.4 & 171 & 100.0 & 3.7 \\
\hline Catalonia & 31 & 4.8 & 0.7 & 611 & 95.2 & 13.1 & 642 & 100.0 & 13.8 \\
\hline Valencian Community & 43 & 7.2 & 0.9 & 558 & 92.8 & 12.0 & 601 & 100.0 & 12.9 \\
\hline Extremadura & 5 & 5.7 & 0.1 & 83 & 94.3 & 1.8 & 88 & 100.0 & 1.9 \\
\hline Galicia & 24 & 9.6 & 0.5 & 227 & 90.4 & 4.9 & 251 & 100.0 & 5.4 \\
\hline Madrid & 73 & 11.5 & 1.6 & 563 & 85.5 & 12.1 & 636 & 100.0 & 13.7 \\
\hline Murcia & 40 & 18.3 & 0.9 & 178 & 81.7 & 3.8 & 218 & 100.0 & 4.7 \\
\hline Navarre & 17 & 23.9 & 0.4 & 54 & 76.1 & 1.2 & 71 & 100.0 & 1.5 \\
\hline Basque Country & 6 & 3.8 & 0.1 & 150 & 96.2 & 3.2 & 156 & 100.0 & 3.3 \\
\hline La Rioja & 19 & 31.7 & 0.4 & 41 & 68.3 & 0.9 & 60 & 100.0 & 1.3 \\
\hline Total & 542 & & 11.6 & 4117 & & 88.4 & 4659 & & 100.0 \\
\hline
\end{tabular}

Table 2. Percentages and frequencies of training received by Teacher Degree students according to the Autonomous Community

If one considers training according to the university, the results show that $88.5 \%$ ( $n=4137$ ) of students from public universities have not received training in cinema and $87.0 \%(\mathrm{n}=468)$ of students from private universities have not either. 


\subsection{Subjects with Specific Content for Didactic Use of Cinema}

Table 3 shows the results obtained on the number of subjects in which the students participating in the Teacher's Degree have identified specific content on the didactic use of cinema, depending on the Autonomous Community where it is taught and the university.

\begin{tabular}{|c|c|c|c|c|}
\hline \multirow[b]{2}{*}{ Autonomous communities } & \multirow[b]{2}{*}{ Universities } & \multicolumn{3}{|c|}{ Subjects } \\
\hline & & f & $\begin{array}{c}\% \\
\text { AACC }\end{array}$ & $\begin{array}{c}\% \\
\text { Spain }\end{array}$ \\
\hline \multirow{9}{*}{ Andalusia } & Almería & 1 & 2.0 & 0.4 \\
\hline & Cádiz & 5 & 10.0 & 2.0 \\
\hline & Córdoba & 2 & 4.0 & 0.8 \\
\hline & Granada & 6 & 12.0 & 2.4 \\
\hline & Huelva & 3 & 6.0 & 1.2 \\
\hline & Jaén & 5 & 10.0 & 2.0 \\
\hline & Loyola & 5 & 10.0 & 2.0 \\
\hline & Málaga & 13 & 26.0 & 5.2 \\
\hline & Sevilla & 10 & 20.0 & 4.0 \\
\hline Total Andalusia & & 50 & 100.0 & 20.0 \\
\hline \multirow{2}{*}{ Aragon } & San Jorge & 3 & 75.0 & 1.2 \\
\hline & Zaragoza & 1 & 25.0 & 0.4 \\
\hline Total Aragon & & 4 & 100.0 & 1.6 \\
\hline Asturias & Oviedo & 9 & 100.0 & 3.6 \\
\hline Total Asturias & & 9 & 100.0 & 3.6 \\
\hline Balearic Islands & Islas Baleares & 2 & 100.0 & 0.8 \\
\hline Total Balearic Islands & & 2 & 100.0 & 0.8 \\
\hline \multirow{2}{*}{ Canary Islands } & La Laguna & 1 & 20.0 & 0.4 \\
\hline & Las Palmas & 4 & 80.0 & 1.6 \\
\hline Total Canary Islands & & 5 & 100.0 & 2.0 \\
\hline \multirow{2}{*}{ Cantabria } & Cantabria & 7 & 77.7 & 2.8 \\
\hline & European Atlantic & 2 & 22.2 & 0.8 \\
\hline Total Cantabria & & 9 & 100.0 & 3.6 \\
\hline Castilla-La Mancha & Castilla-La Mancha & 6 & 100.0 & 2.4 \\
\hline Total Castilla-La Mancha & & 6 & 100.0 & 2.4 \\
\hline \multirow{6}{*}{ Castile and Leon } & Burgos & 2 & 8.3 & 0.4 \\
\hline & Catholic S.T. de Jesús de Avila & 0 & 0.0 & 0.0 \\
\hline & León & 3 & 12.5 & 1.6 \\
\hline & Pontifical of Salamanca & 1 & 6.6 & 0.4 \\
\hline & Salamanca & 7 & 46.6 & 2.8 \\
\hline & Valladolid & 2 & 13.3 & 0.8 \\
\hline Total Castile and Leon & & 15 & 100.0 & 6.0 \\
\hline \multirow{8}{*}{ Catalonia } & Autonomous of Barcelona & 2 & 8.3 & 0.8 \\
\hline & Barcelona & 3 & 12.5 & 1.2 \\
\hline & Girona & 4 & 16.6 & 1.6 \\
\hline & International of Cataluña & 0 & 0.0 & 0.0 \\
\hline & Lleida & 8 & 33.3 & 3.2 \\
\hline & Ramon Llull & 1 & 4.1 & 0.4 \\
\hline & Rovira i Virgili & 2 & 8.3 & 0.8 \\
\hline & Vic & 4 & 16.6 & 1.6 \\
\hline Total Catalonia & & 24 & 100.0 & 9.6 \\
\hline
\end{tabular}




\begin{tabular}{|c|c|c|c|c|}
\hline \multirow[b]{2}{*}{ Autonomous communities } & \multirow[b]{2}{*}{ Universities } & \multicolumn{3}{|c|}{ Subjects } \\
\hline & & f & $\begin{array}{c}\% \\
\text { AACC }\end{array}$ & $\begin{array}{c}\% \\
\text { Spain }\end{array}$ \\
\hline \multirow{5}{*}{ Valencian Community } & Alicante & 9 & 50.0 & 3.6 \\
\hline & Valencia Catholic San Vicente Mártir & 0 & 0.0 & 0.0 \\
\hline & CEU Cardenal Herrera & 3 & 16.6 & 1.2 \\
\hline & Jaume I & 1 & 5.5 & 0.4 \\
\hline & Valencia & 5 & 27.7 & 2.0 \\
\hline Total Valencian Community & & 18 & 100.0 & 7.2 \\
\hline Extremadura & Extremadura & 6 & 100.0 & 2.4 \\
\hline Total Extremadura & & 6 & 100.0 & 2.4 \\
\hline \multirow{3}{*}{ Galicia } & A Coruña & 9 & 52.9 & 3.6 \\
\hline & Compostela & 1 & 5.8 & 0.4 \\
\hline & Vigo & 7 & 41.1 & 2.8 \\
\hline Total Galicia & & 17 & 100.0 & 6.8 \\
\hline \multirow{9}{*}{ Madrid } & Alcalá & 11 & 25.5 & 4.4 \\
\hline & Alfonso X El sabio & 1 & 2.3 & 0.4 \\
\hline & Nebrija & 2 & 4.6 & 0.8 \\
\hline & Autonomous of Madrid & 2 & 4.6 & 0.8 \\
\hline & Camilo José Cela & 3 & 6.9 & 1.2 \\
\hline & Complutense & 2 & 4.6 & 0.8 \\
\hline & Francisco de Vitoria & 0 & 0.0 & 0.0 \\
\hline & Comillas Pontifical & 6 & 13.9 & 2.4 \\
\hline & Rey Juan Carlos & 16 & 37.2 & 6.4 \\
\hline Total Madrid & & 43 & 100.0 & 17.2 \\
\hline \multirow{2}{*}{ Murcia } & Catholic San Antonio & 7 & 36.8 & 2.8 \\
\hline & Murcia & 12 & 63.1 & 4.8 \\
\hline Total Murcia & & 19 & 100.0 & 7.6 \\
\hline \multirow{2}{*}{ Navarre } & Navarra & 5 & 71.4 & 2.0 \\
\hline & Public of Navarra & 2 & 28.5 & 0.8 \\
\hline Total Navarre & & 7 & 100.0 & 2.8 \\
\hline \multirow{3}{*}{ Basque Country } & Deusto & 0 & 0.0 & 0.0 \\
\hline & Mondragón & 0 & 0.0 & 0.0 \\
\hline & País Vasco & 7 & 100.0 & 2.8 \\
\hline Total Basque Country & & 7 & 100.0 & 2.8 \\
\hline La Rioja & La Rioja & 9 & 100.0 & 3.6 \\
\hline Total La Rioja & & 9 & 100.0 & 3.6 \\
\hline Total Spain & & 250 & & 100.0 \\
\hline
\end{tabular}

Table 3. Subjects with content on the didactic use of cinema according to the Autonomous Community and the university

There are 250 subjects throughout Spain where specific content on the didactic use of cinema is taught and all the Autonomous Communities have at least one university in whose Teacher's Degree some of these subjects exist. It should be noted that Andalusia and Madrid are the communities in which more subjects with such specific content are taught, 50 and 43 subjects respectively, covering $37.2 \%$ of the total number of subjects in Spain. Catalonia, Murcia and Valencian Community are also three Communities with a considerable number of subjects with 24,19 and 18 subjects each. Nonetheless, the majority of the communities have fewer than 10 subjects, with the Balearic Islands being the community where fewer subjects are taught, specifically 2. The two universities with the most subjects are the Rey Juan Carlos University and the University of Málaga, 16 and 13 subjects, which in turn belong to the two communities 
with the most subjects on the didactic use of cinema. As universities where more than 10 subjects are taught, it is also worth mentioning Murcia and Alcalá, with 13 and 11 respectively. The majority of universities, 27 of the 52 universities, have between 1 and 4 subjects with specific content. In this sense, it is worth mentioning that the University of Girona, the University of Las Palmas, the University of León and the University of Vic have 4 subjects, and with 3 or fewer subjects there are the University of Barcelona, the Autonomous University of Madrid and the University of Compostela, among others.

Figures 2 and 3 present the results regarding the percentage of subjects where specific content on the didactic use of cinema is taught according to the type of university and the Teacher's Degree.

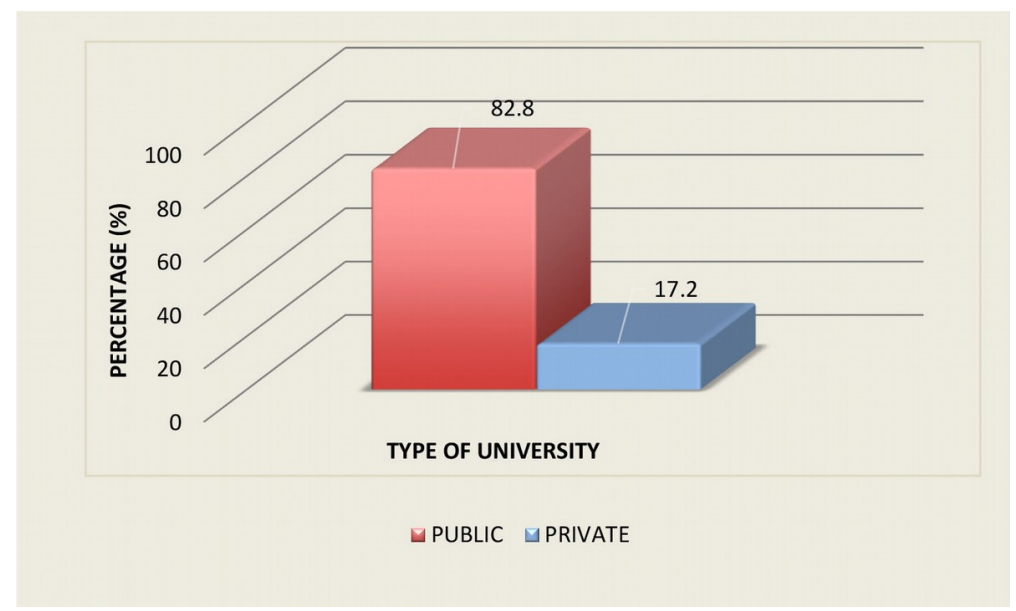

Figure 2. Percentage of subjects with content on the didactic use of cinema according to the type of university

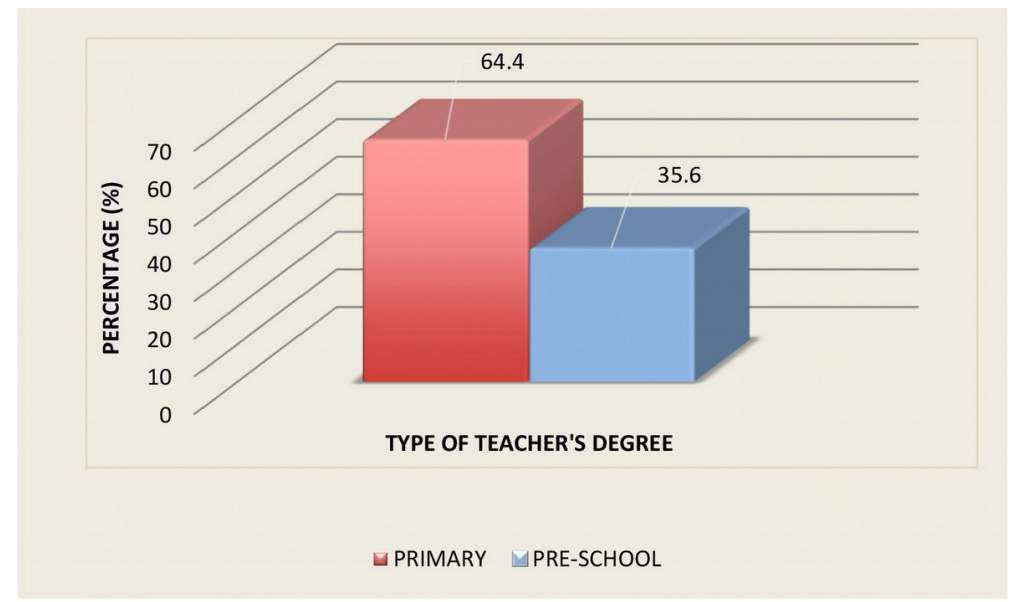

Figure 3. Percentage of subjects with content on the didactic use of cinema according to the Teacher's Degree

As can be seen, most of the subjects where content on the didactic use of cinema is taught come from public universities $(82.8 \%$; $\mathrm{n}=207)$. It is also noted that in the Primary Education Teacher's Degree a higher percentage of subjects of the mentioned profile are taught, $64.4 \%(\mathrm{n}=161)$ of subjects.

As far as the course is concerned, subjects have been identified in all the courses, although it is in the first two years that there is a higher percentage of subjects, $32.0 \%$ in the second year $(n=80)$ and $30.8 \%(n=77)$ in the first year, with the fourth year being the one with the fewest subjects $(10.0 \% ; n=25)$. Figure 4 shows the results obtained on the percentage of subjects that include contents on the didactic use of cinema according to its typology. 


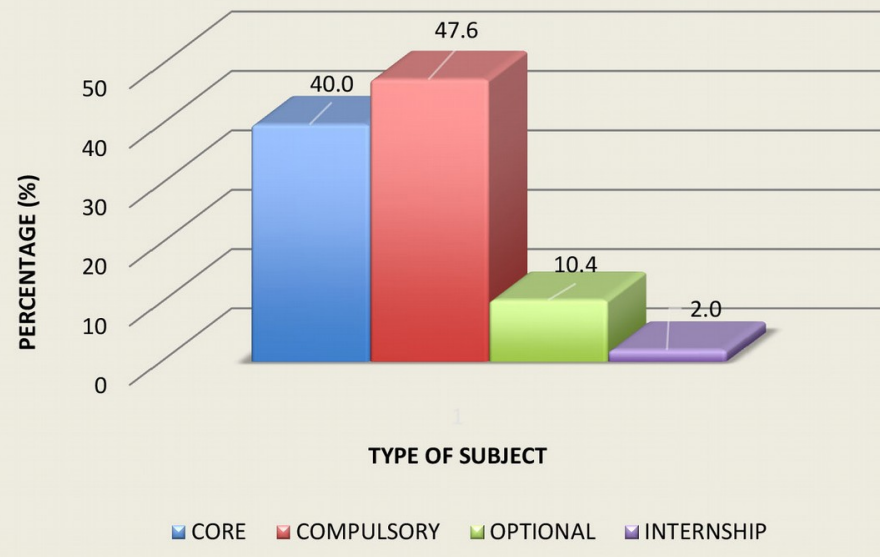

Figure 4. Percentage of subjects with content on the didactic use of cinema according to the type of subject

From the results presented, it can be seen that the highest percentage of subjects where specific cinema content is taught are compulsory $(47.6 \% ; \mathrm{n}=119)$, although there is also a high percentage of core subjects $(40.0 \% ; \mathrm{n}=100)$. In relation to the time placement of subjects with specific film content and their calculation in credits, only $8.0 \%(\mathrm{n}=20)$ are annual and $46.8 \%(\mathrm{n}=117)$ are from the second semester. Furthermore, $80.4 \%$ of the subjects $(n=201)$ are six credits, $5.6 \%(n=14)$ are three credits and $4.4 \%$ $(n=11)$ are nine credits. It should be added that the subjects of four, four and a half and twelve credits have respectively the same percentage $(1.6 \% ; n=4)$. The subjects of five, eight and fifteen credits also have respectively the same percentage $(1.2 \% ; \mathrm{n}=3)$. Finally, the subjects of eighteen, twenty and twenty-four credits have respectively $0.4 \%(n=1)$.

As for the areas of knowledge in which the subjects identified by the students of the Teacher's Degree are framed, where they have received content for the didactic use of cinema, there is a notable diversity, specifically, 29 different areas. Most of the areas, 16 of them, have between 1 and 3 subjects. The two most outstanding areas, which bring together the highest percentage of subjects, are Didactics and School Organization and Language and Literature Teaching with 24.0\% $(\mathrm{n}=60)$ and $13.6 \%(\mathrm{n}=34)$ respectively. It is also worth mentioning as areas with a notable number of subjects, more than 18 subjects, the areas of Didactics of Social Sciences $(10.0 \% ; n=25)$, Didactics of Plastic Expression $(9.2 \% ; n=23)$ and Evolutionary and Educational Psychology $(7.6 \% ; \mathrm{n}=19)$. With a percentage of subjects lower than $7.0 \%$, the areas of Sociology $(6.0 \%$; $\mathrm{n}=15)$, Educational Theory $(5.2 \% ; \mathrm{n}=13)$, Musical Expression Didactics $(4.4 \% ; n=11)$, Interdisciplinary $(3.2 \% ; n=8)$, English Philosophy $(2.8 \% ; n=7)$, Communication $(2.0 \%$; $\mathrm{n}=5)$, Music $(1.6 \% ; n=4)$, Didactics of Experimental Sciences $(1.6 \% ; n=4)$, Didactics of Body Language $(1.2 \% ; \mathrm{n}=3)$, Didactics of Mathematics $(1.2 \% ; \mathrm{n}=3)$, Education $(0.8 \% ; \mathrm{n}=2)$ and Audiovisual Communication and Advertising $(0.8 \% ; \mathrm{n}=2)$. With only one subject $(0.4 \%)$ there are the areas of Contemporary History, Spanish Literature, Catalan Philosophy, Social Anthropology, Pedagogy, Didactics of History, Didactics of English Literature, Languages and Computer Systems, Social Psychology, Physical and Sports Education, Ancient History and Research Methods.

On the other hand, Table 4 presents the 26 subjects that have identified the most specific content on the educational use of cinema.

As can be seen, the subject with the most participating students (9.4\%) who have received training in specific content on the didactic use of cinema is Media Education and the educational dimension of ICT at the University of Córdoba. This is a core subject and is taught in the Degree of Teacher in Pre-school Education. The second subject with the most students (4.4\%) is Education for Citizenship and Human Rights, which is taught in the Primary School Teacher's Degree at the University of Málaga and is compulsory. Other subjects with an outstanding percentage of students, all of them in the Degree of Teacher in Primary Education, are Didactics of Reading and Writing (2.9\%) from the University of Alicante, Audiovisual Communication and 
Education (2.5\%) from the University Rey Juan Carlos and Information and Communication Technology Applied to Education $(2.2 \%)$ from the University of Oviedo. It is worth mentioning that Cantabria is the university with the most subjects among the 26 universities with the most students, with 4 subjects, and Andalusia is the Autonomous Community with the most subjects, with five subjects.

\begin{tabular}{|c|c|c|c|c|c|c|c|}
\hline \multirow[b]{2}{*}{ Subject } & \multirow[b]{2}{*}{ Univer. } & \multirow[b]{2}{*}{ Degree } & \multirow[b]{2}{*}{ Type* } & \multirow[b]{2}{*}{ Cred. } & \multirow[b]{2}{*}{ Knowledge area } & \multicolumn{2}{|c|}{$\begin{array}{l}\text { Participating } \\
\text { students }\end{array}$} \\
\hline & & & & & & $\mathbf{f}$ & $\%$ \\
\hline $\begin{array}{l}\text { Communication and socio- } \\
\text { cultural media: teaching and } \\
\text { learning }\end{array}$ & Alcalá & Primary & COR. & 6 & Communication & 6 & 0.9 \\
\hline Didactics of Social Sciences & Alcalá & Primary & COM. & 6 & $\begin{array}{l}\text { Didactics of Social } \\
\text { Sciences }\end{array}$ & 5 & 0.7 \\
\hline $\begin{array}{l}\text { Didactics of Reading and } \\
\text { Writing }\end{array}$ & Alicante & Primary & COM. & 6 & $\begin{array}{l}\text { Didactics of } \\
\text { Language and } \\
\text { Literature }\end{array}$ & 20 & 2.9 \\
\hline $\begin{array}{l}\text { Communication and } \\
\text { Information Technology in } \\
\text { Education }\end{array}$ & Cádiz & Primary & OPT. & 6 & $\begin{array}{l}\text { Didactics and School } \\
\text { Organization }\end{array}$ & 9 & 1.3 \\
\hline $\begin{array}{l}\text { Curriculum development in } \\
\text { the social field }\end{array}$ & Cantabria & Primary & COM. & 6 & $\begin{array}{l}\text { Educational and } \\
\text { Developmental } \\
\text { Psychology }\end{array}$ & 11 & 1.6 \\
\hline $\begin{array}{l}\text { Education of the gaze: } \\
\text { Cinema and School }\end{array}$ & Cantabria & Primary & OPT. & 6 & $\begin{array}{l}\text { Didactics of Social } \\
\text { Sciences }\end{array}$ & 5 & 0.7 \\
\hline $\begin{array}{l}\text { Education of the gaze: } \\
\text { Cinema and School }\end{array}$ & Cantabria & Pre-School & OPT. & 6 & $\begin{array}{l}\text { Didactics of Social } \\
\text { Sciences }\end{array}$ & 5 & 0.7 \\
\hline $\begin{array}{l}\text { Culture, environment and } \\
\text { teaching of the social }\end{array}$ & Cantabria & Primary & COR. & 6 & $\begin{array}{l}\text { Didactics of Social } \\
\text { Sciences }\end{array}$ & 12 & 1.8 \\
\hline $\begin{array}{l}\text { Media, materials and new } \\
\text { technologies applied to } \\
\text { education }\end{array}$ & $\begin{array}{l}\text { Catholic } \\
\text { San } \\
\text { Antonio }\end{array}$ & Primary & COR. & 6 & Education & 5 & 0.7 \\
\hline $\begin{array}{l}\text { Media education and the } \\
\text { educational dimension of } \\
\text { ICT }\end{array}$ & Córdoba & Pre-School & COR. & 8 & $\begin{array}{l}\text { Didactics and school } \\
\text { organization }\end{array}$ & 64 & 9.4 \\
\hline $\begin{array}{l}\text { Science and its Didactics in } \\
\text { Pre-school Education }\end{array}$ & Granada & Pre-School & COM. & 6 & $\begin{array}{l}\text { Didactics of } \\
\text { Experimental } \\
\text { Sciences } \\
\end{array}$ & 5 & 0.7 \\
\hline $\begin{array}{l}\text { Didactics of Social } \\
\text { Sciences: History }\end{array}$ & La Rioja & Primary & COM. & 6 & $\begin{array}{l}\text { Didactics of Social } \\
\text { Sciences }\end{array}$ & 14 & 2.0 \\
\hline $\begin{array}{l}\text { Literary and Aesthetic } \\
\text { Education in Primary } \\
\text { Education }\end{array}$ & Las Palmas & Primary & COM. & 6 & $\begin{array}{l}\text { Didactics of } \\
\text { Language and } \\
\text { Literature }\end{array}$ & 10 & 1.5 \\
\hline $\begin{array}{l}\text { Digital technologies in } \\
\text { primary education }\end{array}$ & Lleida & Primary & COR. & 6 & $\begin{array}{l}\text { Didactics and School } \\
\text { Organization }\end{array}$ & 8 & 1.2 \\
\hline Visual arts & Lleida & Primary & COM. & 6 & $\begin{array}{l}\text { Didactics of Musical } \\
\text { Expression }\end{array}$ & 7 & 1.0 \\
\hline $\begin{array}{l}\text { Artistic Creation and } \\
\text { Research Workshop }\end{array}$ & Murcia & Primary & COM. & 6 & $\begin{array}{l}\text { Didactics and School } \\
\text { Organization }\end{array}$ & 6 & 0.9 \\
\hline $\begin{array}{l}\text { Alternative and } \\
\text { Augmentative } \\
\text { Communication Systems }\end{array}$ & Murcia & Primary & OPT. & 3 & $\begin{array}{l}\text { Didactics and School } \\
\text { Organization }\end{array}$ & 6 & 0.9 \\
\hline $\begin{array}{l}\text { Media, materials and ICT } \\
\text { for teaching }\end{array}$ & Murcia & Pre-School & COR. & 6 & $\begin{array}{l}\text { Didactics and School } \\
\text { Organization }\end{array}$ & 10 & 1.5 \\
\hline $\begin{array}{l}\text { Education for Citizenship } \\
\text { and Human Rights }\end{array}$ & Málaga & Primary & COM. & 6 & Education Theory & 30 & 4.4 \\
\hline
\end{tabular}




\begin{tabular}{|c|c|c|c|c|c|c|c|}
\hline \multirow[b]{2}{*}{ Subject } & \multirow[b]{2}{*}{ Univer. } & \multirow[b]{2}{*}{ Degree } & \multirow[b]{2}{*}{ Type* } & \multirow[b]{2}{*}{ Cred. } & \multirow[b]{2}{*}{ Knowledge area } & \multicolumn{2}{|c|}{$\begin{array}{l}\text { Participating } \\
\text { students }\end{array}$} \\
\hline & & & & & & $\mathrm{f}$ & $\%$ \\
\hline General Didactics & Málaga & Primary & COR. & 9 & $\begin{array}{l}\text { Didactics and School } \\
\text { Organization }\end{array}$ & 5 & 0.7 \\
\hline $\begin{array}{l}\text { Plastic and audiovisual } \\
\text { education I }\end{array}$ & Navarra & Primary & COM. & 3 & $\begin{array}{l}\text { Didactics of Plastic } \\
\text { Expression }\end{array}$ & 10 & 1.5 \\
\hline $\begin{array}{l}\text { Information and } \\
\text { Communication } \\
\text { Technology Applied to } \\
\text { Education }\end{array}$ & Oviedo & Primary & COR. & 6 & $\begin{array}{l}\text { Didactics and School } \\
\text { Organization }\end{array}$ & 15 & 2.2 \\
\hline $\begin{array}{l}\text { Information and } \\
\text { Communication } \\
\text { Technology Applied to } \\
\text { Education }\end{array}$ & Oviedo & Pre-School & COR. & 6 & $\begin{array}{l}\text { Didactics and School } \\
\text { Organization }\end{array}$ & 12 & 1.8 \\
\hline $\begin{array}{l}\text { Audiovisual } \\
\text { Communication and } \\
\text { Education }\end{array}$ & $\begin{array}{l}\text { Rey Juan } \\
\text { Carlos }\end{array}$ & Pre-School & COR. & 6 & $\begin{array}{l}\text { Audiovisual } \\
\text { Communication and } \\
\text { Advertising }\end{array}$ & 12 & 1.8 \\
\hline $\begin{array}{l}\text { Audiovisual } \\
\text { Communication and } \\
\text { Education }\end{array}$ & $\begin{array}{l}\text { Rey Juan } \\
\text { Carlos }\end{array}$ & Primary & COR. & 6 & $\begin{array}{l}\text { Audiovisual } \\
\text { Communication and } \\
\text { Advertising }\end{array}$ & 17 & 2.5 \\
\hline Social science learning & Vigo & Pre-School & COM. & 6 & $\begin{array}{l}\text { Didactics of Social } \\
\text { Sciences }\end{array}$ & 8 & 1.2 \\
\hline
\end{tabular}

${ }^{*}$ COR.=Core; COM. $=$ Compulsory; OPT. $=$ Optional

Table 4. List of the 26 subjects with the highest percentage of participating students where content on the didactic use of cinema is taught

In terms of the number of hours they have received training on the use of cinema as a teaching resource, the majority of students $(82.3 \% ; n=446)$ have received between one and twenty hours of training.

\subsection{Activities with the Cinema as a Didactic Resource}

The following table 5 presents the results of the activities that the teachers of the Teacher's Degree implement with the cinema as a didactic resource according to its frequency of application.

\begin{tabular}{|c|c|c|c|c|c|c|c|c|c|c|c|}
\hline \multirow[b]{2}{*}{ Type of activities } & \multicolumn{2}{|c|}{$\begin{array}{l}\text { Nothing } \\
\text { frequent }\end{array}$} & \multicolumn{2}{|c|}{$\begin{array}{c}\text { Little } \\
\text { frequent }\end{array}$} & \multicolumn{2}{|c|}{$\begin{array}{l}\text { Moderately } \\
\text { frequent }\end{array}$} & \multicolumn{2}{|c|}{$\begin{array}{c}\text { Quite } \\
\text { frequent }\end{array}$} & \multicolumn{2}{|c|}{$\begin{array}{l}\text { Very much } \\
\text { frequent }\end{array}$} & \multirow[b]{2}{*}{$\mathbf{M}$} \\
\hline & f & $\%$ & f & $\%$ & f & $\%$ & f & $\%$ & f & $\%$ & \\
\hline $\begin{array}{l}\text { Viewing film and } \\
\text { individual responses }\end{array}$ & 440 & 9.4 & 2058 & 44.2 & 1408 & 30.2 & 593 & 12.7 & 160 & 3.4 & 2.5 \\
\hline Making a short film & 2379 & 51.1 & 1620 & 34.8 & 474 & 10.2 & 160 & 3.4 & 26 & 0.6 & 1.6 \\
\hline Cineforum & 1130 & 24.3 & 1923 & 41.3 & 1031 & 22.1 & 458 & 9.8 & 117 & 2.5 & 2.2 \\
\hline Reading text from a film & 2038 & 43.7 & 1619 & 34.7 & 688 & 14.8 & 259 & 5.6 & 55 & 1.2 & 1.8 \\
\hline Writing text from a film & 1849 & 39.7 & 1639 & 35.2 & 765 & 16.4 & 322 & 6.9 & 84 & 1.8 & 1.9 \\
\hline Making a Storyboard & 2868 & 61.6 & 1231 & 26.4 & 404 & 8.7 & 125 & 2.7 & 31 & 0.7 & 1.5 \\
\hline $\begin{array}{l}\text { Making a Digital } \\
\text { Storytelling }\end{array}$ & 2890 & 62.0 & 1170 & 25.1 & 443 & 9.5 & 121 & 2.6 & 35 & 0.8 & 1.5 \\
\hline Editing of a trailer & 3295 & 70.7 & 941 & 20.2 & 304 & 6.5 & 89 & 1.9 & 30 & 0.6 & 1.4 \\
\hline $\begin{array}{l}\text { Representation of a film } \\
\text { scene (role-playing) }\end{array}$ & 2578 & 55.3 & 1249 & 26.8 & 538 & 11.5 & 230 & 4.9 & 64 & 1.4 & 1.7 \\
\hline
\end{tabular}

Table 5. Percentages and frequency of activities in the Teacher's Degree with cinema as a didactic resource

The results obtained show that teachers in the Teacher Degrees rarely or never conduct activities in which cinema is the didactic resource, with combined response percentages in these two categories above $53.6 \%$ and mean below 3. Among the most applied activities, it should be noted that $30.2 \%$ of students have 
moderately frequently watched a film in class and have responded individually to questions, and $22.1 \%$ have participated moderately frequently in Cineforum. Less common activities included the editing of a trailer, which was not at all frequent for $70.7 \%$, and digital storytelling, which was not at all frequent for $62.0 \%$.

\subsection{Need for More Training in the Use of Cinema}

In relation to the results on the need expressed by students in the Teacher's Degree for more specific training in the use of cinema as a teaching resource in the classroom, Figure 5 is presented.

As can be seen, $91.5 \%$ of students perceive that they need more training to apply cinema in the classroom, highlighting that $75.1 \%(\mathrm{n}=3499)$ quite and totally agree with this need. On the contrary, only $2.6 \%$ $(n=119)$ of the students totally disagree with the need for more training in the use of cinema in the classroom.

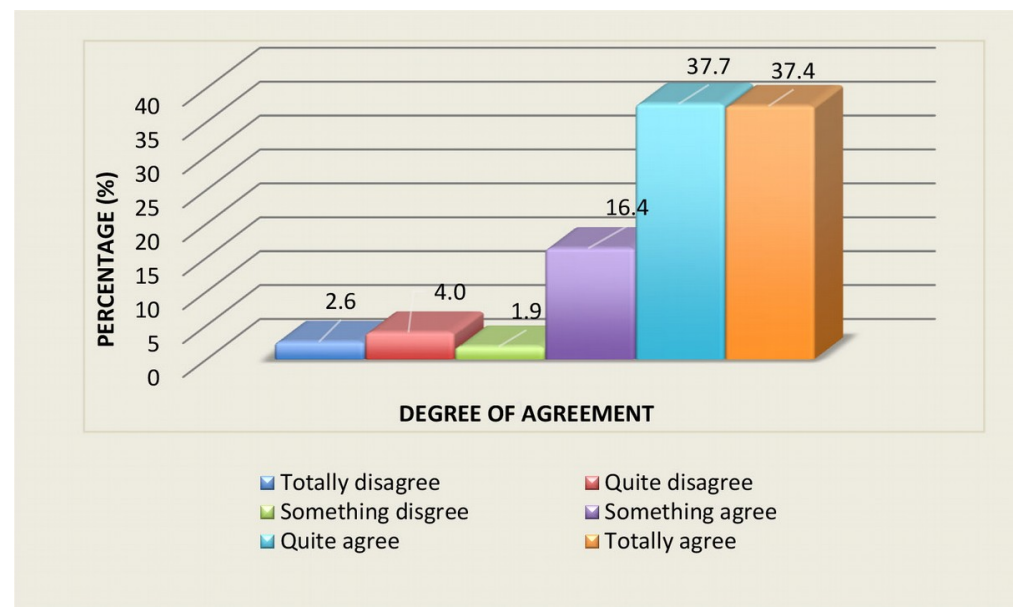

Figure 5. Percentages of responses given on the need for training in the didactic use of cinema

\section{Discussion}

Bearing in mind the objectives set out in the study, one of the findings obtained was the high percentage $(88.4 \%)$ of students in the Teacher's Degree at national level who have not received specific training to use film as a teaching resource in Pre-school and Primary Education classrooms. This high number of students without specific training is in line with the results obtained by Masanet \& Ferrés (2013) and Cabero \& Guerra (2011), which, in the field of Media Education, revealed significant training deficiencies. Lorenzo-Lledó \& Roig-Vila (2017) also detected, in the specific case of the University of Alicante, insufficient training in the use of cinema in the classroom. This fact is important for the future application of cinema in the classroom, since, as Lorenzo-Lledó, Lledó and Lorenzo (2020) have observed, students who have received specific training perceive the educational potential of cinema more intensely. On the other hand, it has been observed that teachers of the Teacher's Degree do not usually implement activities where they use cinema as a didactic resource. This means that students, in addition to not receiving specific training in the didactic use of film, do not usually participate in activities with cinema either. In this way, they are also prevented from learning to use cinema through vicarious learning, which is an effective strategy in the training of university students (Criollo, Romero \& Fontaines Ruiz, 2017). It should be added that when teachers in the Teacher's Degree choose activities with cinema, they more frequently watch a film with individual answers to questions and the Cineforum. This means that they choose to implement the more traditional activities with cinema (Martín, 2014), to the detriment of more innovative, diverse and procedural activities, which require greater training of both teachers and students, such as, for example, the editing of a trailer, the making of a short film or a storyboard. Nevertheless, the educational shortcomings detected are partly made up for, as shown by Lorenzo-Lledó, Lledó, Pérez-Vázquez and 
Lorenzo (2020), with a regular habit of watching films a week by students in the Teacher's Degree, which means a way to access the cinema and non-formal training.

If we consider the Autonomous Communities in order to identify which students in Spain have received more training, the study has shown that the communities with the most training are Cantabria and Asturias, so that, with the exception of these communities, more than $68.0 \%$ of the students in the different communities have not received any training. In this sense, the community with the highest percentage of untrained students is the Basque Country, which is in turn the community with the lowest frequency of film consumption per week among Teacher Training students in Spain (Lorenzo-Lledó, Lledó, Pérez-Vázquez et al., 2020). On the other hand, if we take the type of Teacher's Degree and the type of university of the student body, these variables do not turn out to be a differentiating factor, reflecting in both cases very high percentages of untrained students. Nevertheless, despite the similarities in the results, the percentage of untrained students in the Pre-school Education Teacher's Degree and in public universities is slightly higher.

Regarding the subjects of the Teacher's Degree where specific contents on the didactic use of cinema are taught, in accordance with the low training, in the study 250 subjects were found all over Spain. Masanet and Ferrés (2013) identified 214 subjects with Media Education content in university degrees in the field of education, although with a smaller sample. However, no Autonomous Community was found where no subjects with such content were taught. Thus, Andalusia and Madrid are the Communities with the most subjects, 50 and 43, which could be due to the fact that they are also the Communities with the most universities and the largest student population. However, Catalonia has only one university less than Madrid and the same as Andalusia and has a high percentage of student population and, despite this, has 24 subjects, which shows that Andalusia and Madrid have training indices that are among the highest and that they are two communities whose universities should be taken into account in their training plans as a reference.

Similarly, a greater number of subjects have been found in public universities than in private universities, where no subjects with such content are offered in 6 universities, although the difference in the number of universities of one type or another must be borne in mind. Furthermore, it has been found that students in the Primary Education Teacher Degree take more subjects with specific content on cinema, which is in line with the finding that they have slightly more training. It should be borne in mind that the cinema is a more present audiovisual medium in the contents and objectives of the Primary Education stage (Lara et al., 2019), and therefore it is coherent that it has a greater role in the initial training of primary school teachers. On the other hand, the scarce training that students receive in the Teacher Degree is mainly in the initial courses, since $62.5 \%$ of the subjects with such content are taught in the first and second years, a finding also in line with the fact that most of these subjects are core and compulsory.

The few specific contents received by students of the Teacher's Degree from Spanish universities on the didactic use of cinema are included within other subjects with broader contents, with the exception of one specific subject found at the University of Cantabria, called Education of the Gaze: cinema and education, of an optional type. However, more subjects have been found, which, although not specifically dedicated to cinema, are included in Media Education and audiovisual communication. Another important area where students also receive this training is in ICT subjects, with the risk that this entails, as Gutiérrez (2003) and Ferrés (2006) warned, that the technological or instrumental aspect is given greater priority than the critical-reflective one and that the cinematographic aspect is diluted in the generic and often confusing concept of ICT. Nevertheless, the area of knowledge from which a greater percentage of subjects $(24.0 \%)$ come is Didactics and School Organization, reflected in a greater emphasis on the study of didactic methodologies to be applied with the cinema in the educational context.

\section{Conclusions}

Based on the proposed objectives and according to the findings, the following conclusions are indicated: 
1. The training received in Spain in the Teacher's Degree for the didactic use of cinema is a minority, with a very high percentage of untrained students.

2. Specific content for the educational use of cinema is taught in 250 subjects throughout Spain. These are mostly core and compulsory, belonging mainly to the first two years, are more present in the Degree of Primary Education Teacher and come mainly from the areas of Didactics and School Organization and Didactics of Language and Literature.

3. It is rare or not at all frequent that teachers of the Teacher's Degree implement activities where they use the cinema as a didactic resource, as is the case with the viewing of a film with individual answers to questions and the Cineforum.

4. In view of the lack of training received, the students of the Teacher's Degree detected a lack in their initial teacher training, stating that they would need more specific training in the use of cinema as a didactic resource in the classroom.

As a limitation of the study, it is worth mentioning the fact that five Spanish private universities did not agree to collaborate in the research. This made it impossible to form a wider and more diverse sample with the participation of students from all Spanish universities.

The study presented is a pioneer in the analysis throughout Spain of the presence of training in the Teacher Degree students for the didactic use of cinema, and therefore opens a line of research for other studies, both national and international, that complement it from different approaches. On a practical level, the training deficiencies detected recommend deepening, with specific plans, the training for the effective application of this resource in favour of the improvement of the teaching-learning processes in Pre-school and Primary Education. This training should be extended to all the Autonomous Communities, although with even greater intensity in those where a greater number of untrained students have been identified. If the cinema is a resource with educational value that does not require a very expensive economic investment and is also a popular medium among future teachers, it can be said that the possibilities of implementing training for the didactic use of the cinema are greater. This training can be implemented through a specific subject or in a transversal way in several areas of knowledge. The essential thing is that the training covers the three educational dimensions detected in the cinema: as a didactic resource of the transmission of content, as a didactic resource of expression and communication, and as a didactic resource of critical analysis (Lorenzo-Lledó, 2020). In this sense, the training should address the educational use of cinema with the training to create learning activities through cinema, without forgetting its aspect as an audiovisual language and a means of artistic expression and as a means to enhance the critical and autonomous development of students. The incorporation of cinema in the initial teacher training must be precise, with links to the curricular design and previously defining the didactic objectives to be pursued. Films, as didactic resources, should be selected for their educational and cultural value and be worked on according to certain guidelines. In this way, the planning of a global pedagogical strategy with the active involvement of teachers and educational institutions is recommended for the optimal application of cinema.

\section{Declaration of Conflicting Interests}

The authors declared no potential conflicts of interest with respect to the research, authorship, and/or publication of this article.

\section{Funding}

The authors received no financial support for the research, authorship, and/or publication of this article.

\section{References}

Amar, V. (2009). El cine en la encrucijada de la educación y el conocimiento. Enl@ce, 6(2), 131-140.

Ambròs, A., \& Breu, R. (2011). El cine en la escuela: Propuestas didácticas de películas para primaria y secundaria. Barcelona: Grao. 
Arnau, J. (1996). Model general d'investigación psicológica. Barcelona: UOC.

Arráez, R., Jensen, E., \& Pascual, C. (2013). Periodistas culturales y teatro en el EEES. Estudios sobre el Mensaje Periodístico, 19, 65-73. https://doi.org/10.5209/rev_ESMP.2013.v19.42012

Bisquerra, R. (2014). Metodología de la investigación educativa. Madrid: La Muralla.

Cabero, J., \& Córdoba, M. (2009). Cine y diversidad social. Instrumento práctico para la formación en valores. Madrid: Editorial MAD.

Cabero, J., \& Guerra, S. (2011). La alfabetización y formación en medios de comunicación en la formación inicial del profesorado. Educación XX1, 14(1), 89-115. https://doi.org/10.5944/educxx1.14.1.264

Cabero, J. (2017). La formación en la era digital: ambientes enriquecidos por la tecnología. Gestión de la Innovación en la Educación Superior, 2(1), 34-53.

Criollo, M., Romero, M., \& Fontaines Ruiz, T. (2017). Autoeficacía para el aprendizaje de la investigación en estudiantes universitarios. Revista de Psicología educativa, 23(1), 63-72.

https://doi.org/10.1016/j.pse.2016.09.002

De la Herrán, A., \& Álvarez, N. (2010). Para qué enseñar: significado y sentido de la formación universitaria. En Paredes, de la H. (Coord.), Cómo enseñar en el aula universitaria (59-74). Madrid: Pirámide.

Ferrés, J. (2006). La educación en comunicación audiovisual en la era digital. Quaderns del CAC, 25(1), 5-8.

Freire, P. (1975). Pedagogía del oprimido. Madrid: SIGLO XXI.

Fuentes, A., López, J., \& Pozo, S. (2019). Análisis de la Competencia Digital Docente: Factor Clave en el Desempeño de Pedagogías Activas con Realidad Aumentada. Revista Iberoamericana sobre calidad, eficacia y cambio en la Educación, 17(2), 29-42. https://doi.org/10.15366/reice2019.17.2.002

Gewerc, A., \& Montero, L. (2015). Conocimiento profesional y competencia digital en la formación del profesorado. El caso del Grado de Maestro en Educación Primaria. RELATEC, Revista Latinoamericana de Tecnología Educativa, 14(1), 31-45.

Gozálvez, V., Masanet, M.J., Hernando, A., \& Bernal-Bravo, C. (2019). Relación entre formación universitaria y competencia mediática del profesorado. Revista Complutense de Educación, 30(4), 1113-1126. https://doi.org/10.5209/rced.60188

Gutiérrez, A. (2003). Alfabetización digital. Algo más que ratones y teclas. Barcelona: Gedisa.

Hernández-Nieto, R.A (2002). Contributions to statistical Analysis. Merida, Venezuela: Universidad de los Andes.

Organic Law 8/2013 for the Improvement of Educational Quality (2013). BOE no. 295, of 30 December 2013.

Organic Law 2/2006 on Education (2006). BOE no. 106, of 4 May 2006.

Lara, F, Ruiz, M., \& Tarín, M. (Coords.) (2019). Cine y educación. Madrid: Academia de las Artes y las Ciencias Cinematográficas de España.

López, L., \& Aguaded, M. (2015). La docencia sobre alfabetización mediática en las facultades de Educación y Comunicación. Comunicar, 22(44), 187-195. https://doi.org/10.3916/C44-2015-20

Lorenzo-Lledó, A. (2020). Design and Validation of a Questionnaire to Measure Future Spanish Teachers' Perceptions of Cinema in Pre-School and Primary Education: Towards Active and Technological Learning. Future Internet, 12(9), 149. https://doi.org/10.3390/ fi12090149

Lorenzo-Lledó, A., Lorenzo, G., Lledó, A., \& Pérez-Vázquez, E. (2020). Inclusive methodologies from the teaching perspective for improving performance in university students with disabilities. Journal of Technology and Science Education, 10(1), 127-141. https://doi.org/10.3926/jotse.887 
Lorenzo-Lledó, A., Lledó, A., \& Lorenzo, G. (2020). Cinema as a Transmitter of Content: Perceptions of Future Spanish Teachers for Motivating Learning. Sustainability, 12(14), 5505.

https://doi.org/10.3390/su12145505

Lorenzo-Lledó, A., Lledó, A., Pérez-Vázquez, E., \& Lorenzo, G. (2020). Cinematographic Habits of Future Spanish Teachers from a Socio-Educational Perspective. International Journal of Environmental Research and Public Health, 17(15), 5361. https:/ /doi.org/10.3390/ijerph17155361

Lorenzo-Lledó, A., \& Roig-Vila, R. (2017). El cine como recurso didáctico: Percepciones de los estudiantes del Grado de Maestro. En Investigación en docencia universitaria: diseñando el futuro a partir de la innovación educativa (305-313). Octaedro.

Martín, F. (2014). La desaparición de los cinefórum como reflejo del ocaso del movimiento cineclubista en la Andalucía de la Transición. Área Abierta, 14(1), 1-14.

Masanet, M., \& Ferrés, J. (2013). La enseñanza universitaria española en materia de educación mediática. Communication Papers, 2(2), 83-90. https://doi.org/10.33115/udg_bib/cp.v2i02.22109

Muñoz, E., \& Cubo, S. (2019). Competencia digital, formación y actitud del profesorado de educación especial hacia las tecnologías de la información y la comunicación (TIC). Revista de Curriculum y Formación del profesorado, 23(1), 210-241. https://doi.org/10.30827/profesorado.v23i1.9151

Order ECI/3854/2007, of 27 December, which establishes the requirements for the verification of official university degrees that enable the exercise of the profession of Pre-school Education Teacher. BOE no.312, 29 December 2007.

Order ECI/3857/2007, of 27 December 2007, which establishes the requirements for the verification of official university degrees that enable the practice of the profession of Primary Education Teacher. BOE no.312, 29 December 2007.

Ortega, D. (2015). La enseñanza de las Ciencias Sociales, las TIC y el tratamiento de la información y competencia digital (TICD) en el Grado de Maestro/a de Educación Primaria de las universidades de Castilla y León. Enseñanza de las Ciencias Sociales, 14, 121-134.

Ramírez, A., Renés, P., \& García-Ruiz, R. (2014). Presencia de la competencia mediática en los objetivos curriculares de la etapa de educación primaria. Teoría de la Educación. Revista Interuniversitaria, 26(1), 137-159. https://dx.doi.org/10.14201/teoredu2014261137159

Ramírez, A., Renés, P., \& Aguaded, I. (2016). La competencia mediática en los criterios de evaluación del currículo de Educación Primaria. Aula Abierta, 44(2), 55-62. https:/ /doi.org/10.1016/j.aula.2015.08.002

Ramírez, A., Renés P., \& González, N. (2018). La competencia mediática a través de los contenidos curriculares en la etapa de educación primaria en España. En La educación mediática en España: artículos creados (399-416). Madrid: Universitas Editorial.

Published by OmniaScience (www.omniascience.com)

Journal of Technology and Science Education, 2021 (www.jotse.org)

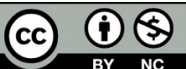

Article's contents are provided on an Attribution-Non Commercial 4.0 Creative commons International License. Readers are allowed to copy, distribute and communicate article's contents, provided the author's and JOTSE journal's names are included. It must not be used for commercial purposes. To see the complete licence contents, please visit https://creativecommons.org/licenses/by-nc/4.0/. 